\title{
Prestasi Belajar dan Perilaku Keagamaan Siswa
}

\author{
Oleh: \\ Haizatul Masnaiyah \\ (MTs Taufiqiyatul Asna Bukaan Keling Kepung Kediri)
}

\begin{abstract}
Abstrak
Tulisan ini bertujuan untuk: mengetahui prestasi belajar, perilaku keagamaan siswa hubungan antara prestasi belajar dengan perilaku keagamaan siswa. Siswa yang dijadikan sampel adalah 87 siswa. Teknik pengumpulan data menggunakan angket dan dokumentasi. Sedangkan metode analisis yang digunakan adalah menggunakan teknik analisis korelasi Tata Jenjang Spearman. Hasil penelitian menunjukkan bahwa (1) Prestasi Prestasi belajar siswa tergolong baik, yaitu mencapai nilai ratarata 82,7. (2) Perilaku keagamaan siswa tergolong baik yaitu dengan prosentase $56,3 \%$ baik, $39,1 \%$ sedang, $2,3 \%$ baik sekali dan 2,3\% kurang. (3) Adanya hubungan yang signifikan antara Prestasi belajar dengan perilaku keagamaan siswa dengan tingkat kekuatan hubungan antara keduanya tergolong sedang. Hal ini berdasarkan dari hasil penghitungan data dengan rumus Tata Jenjang Spearman menggunakan program IBM SPSS Statistics Versi 22 yang menunjukkan nilai korelasi antara variabel $x$ dan variabel y sebesar 0,404 dengan nilai Sig. (2-tailed) $=0,000$.
\end{abstract}

Kata Kunci: Prestasi Belajar, Perilaku Keagamaan.

\section{Abstract}

This paper aims to: determine student achievement, student religious behavior relationship between learning achievement with student religious behavior. Students sampled is 87 students. The technique of collecting data using questionnaires and documentation. While the methods of analysis used is using the technique Spearman correlation analysis Tata offer. The results 
showed that (1) Achievement Student achievement is quite good, reaching an average value of 82.7. (2) Religious behavior of students classified as good ie with a percentage of $56.3 \%$ good, $39.1 \%$ moderate, $2.3 \%$ and $2.3 \%$ splendidly less. (3) There is a significant relationship between academic achievement by religious behavior of students with the level of strength of the relationship between the two moderate. This is based on the results of data calculated by the formula Spearman using IBM SPSS Statistics program version 22, which shows the correlation between the variables $x$ and $y$ variables amounted to 0,404 with the Sig. (2tailed) $=0,000$.

Keywords: Achievement, Religious Behavior.

\section{Pendahuluan}

Pendidikan menurut undang-undang Sisdiknas No.30 tahun 2003 merupakan usaha sadar dan terencana untuk mewujudkan suasana belajar dan proses pembelajaran agar peserta didik secara aktif mengembangkan potensi dirinya untuk memiliki kekuatan spiritual keagamaan, pengendalian diri, kepribadian, kecerdasan, akhlak mulia, serta keterampilan yang diperlukan dirinya, masyarakat, bangsa dan negara. Sebagai usaha sadar dan terencana, pendidikan dalam pelaksanaannya haruslah berada dalam sebuah proses yang berkesinambungan dalam setiap jenis dan jenjang pendidikan yang integral.

Komponen-komponen utama proses pendidikan adalah belajar, berpikir, mengingat, dan pengetahuan. Proses belajar pada hakikatnya adalah komunikasi edukatif yang dapat menimbulkan hubungan timbal balik antara dua hal atau lebih atau pribadi-pribadi yang sama, dengan tujuan mengarahkan dirinya pada satu tujuan tertentu yang akan dicapai. Slameto mendefinisikan belajar sebagai suatu proses usaha yang dilakukan seseorang untuk memperoleh suatu perubahan tingkah laku yang baru secara keseluruhan, sebagai hasil pengalamannya sendiri dalam interaksi dengan lingkungannya. Dengan demikian belajar merupakan sebuah proses yang hasilnya adalah perubahan sikap dan tingkah 
laku, yang mana perubahan sikap dan tingkah laku tersebut oleh Hamalik didefinisikan sebagai prestasi belajar.

Proses-proses perkembangan yang dipandang memiliki keterkaitan langsung dengan kegiatan belajar siswa meliputi:

1) Perkembangan motor (motor development), yakni proses perkembangan yang progresif dan berhubungan dengan perolehan aneka ragam keterampilan fisik anak (motor skills).

2) Perkembangan kognitif (cognitif development), yakni perkembangan fungsi intelektual atau proses perkembangan kemampuan/kecerdasan otak anak.

3) Perkembangan sosial dan moral (social and moral development) yakni proses perkembangan mental yang berhubungan dengan perubahan cara anak dalam berkomunikasi dengan obyek atau orang lain, baik sebagai individu maupun kelompok.

Sekolah sebagai penyelenggara pendidikan sekaligus sebagai tempat berlangsungnya kegiatan belajar memiliki tanggungjawab besar untuk mengembangkan aspek-aspek tersebut sesuai dengan potensi yang dimiliki peserta didik agar menjadi manusia yang beriman dan bertaqwa serta mampu mengembangkan pengetahuannya sesuai dengan syari'at Islam. Agar dapat terwujud perlu diberikan arahan dalam hal ini adalah pendidikan agama. Melalui pendidikan agama ini diharapkan peserta didik dapat mengembangkan potensi taqwa kepada Allah. Apabila potensi ini berkembang dengan baik, maka individu akan mampu mengendalikan potensi kognitifnya supaya tidak terwujud dalam bentuk perilaku yang bertentangan dengan nilai-nilai agama yang telah tertanam dalam dirinya.

Berdasarkan latar belakang di atas, rumusan masalah penelitian ini adalah: (1) Bagaimana prestasi belajar siswa MTs Taufiqiyatul Asna Bukaan Keling Kepung? (2) Bagaimana perilaku keagamaan siswa MTs Taufiqiyatul Asna Bukaan Keling Kepung? (3) Adakah korelasi antara prestasi belajar dengan perilaku keagamaan siswa MTs Taufiqiyatul Asna Bukaan Keling Kepung?. 


\section{Metode Penelitian}

Metode yang digunakan dalam penelitian ini adalah dengan menggunakan metode penelitian kuantitatif korelasional yaitu metode yang bertujuan mendeteksi sejauh mana variasi-variasi pada suatu faktor berkaitan dengan variasi-variasi pada satu atau lebih faktor lain berdasarkan pada koefisien korelasi. Dengan penelitian ini diharapkan dapat diketahui hubungan/korelasi antara prestasi belajar dengan perilaku keagamaan siswa MTs Taufiqiyatul Asna dan seberapa signifikan hubungan tersebut.

Tabel 1 Kisi-Kisi Perilaku Keagamaan

\begin{tabular}{|c|c|c|c|}
\hline Variabel & Aspek & Indikator & No. \\
\hline \multirow[t]{10}{*}{$\begin{array}{l}\text { Perilaku } \\
\text { keagamaa } \\
\text { n siswa }\end{array}$} & $\begin{array}{l}\text { 1. Tanggung } \\
\text { jawab } \\
\text { kepada }\end{array}$ & $\begin{array}{l}\text { 1. Menjalankan ibadah salat } \\
\text { lima waktu tepat pada } \\
\text { waktunya }\end{array}$ & 1 \\
\hline & Allah & $\begin{array}{l}\text { 2. Membiasakan salat dengan } \\
\text { berjama'ah }\end{array}$ & 2 \\
\hline & & $\begin{array}{l}\text { 3. Menjalankan ibadah puasa } \\
\text { ramadlan }\end{array}$ & 3 \\
\hline & & $\begin{array}{l}\text { 4. Memperbanyak amalan- } \\
\text { amalan ibadah sunnah }\end{array}$ & $4,5,6$ \\
\hline & & $\begin{array}{l}\text { 5. Memperbanyak membaca } \\
\text { al-qur'an }\end{array}$ & 7 \\
\hline & & $\begin{array}{l}\text { 6. Menjauhi perbuatan- } \\
\text { perbuatan yang dilarang } \\
\text { oleh agama }\end{array}$ & 8 \\
\hline & $\begin{array}{l}\text { 2. Tanggung } \\
\text { jawab } \\
\text { kepada }\end{array}$ & $\begin{array}{l}\text { 1. Menghormati kedua orang } \\
\text { tua, guru dan orang yang } \\
\text { lebih tua usianya }\end{array}$ & 9,10 \\
\hline & $\begin{array}{l}\text { sesama } \\
\text { manusia }\end{array}$ & $\begin{array}{l}\text { 2. Berperilaku sopan dan } \\
\text { santun kepada guru, orang } \\
\text { tua dan sesama }\end{array}$ & $\begin{array}{l}11,12 \\
13\end{array}$ \\
\hline & & $\begin{array}{l}\text { 3. Menyayangi dan } \\
\text { menghargai sesama teman }\end{array}$ & 14,15 \\
\hline & $\begin{array}{l}\text { 3. Tanggung } \\
\text { jawab } \\
\text { kepada } \\
\text { alam sekitar }\end{array}$ & $\begin{array}{l}\text { 1. Menjaga kebersihan dan } \\
\text { kelestarian lingkungan }\end{array}$ & $\begin{array}{l}16,17 \\
18\end{array}$ \\
\hline
\end{tabular}


Populasi dalam penelitian ini adalah seluruh siswa siswi MTs Taufiqiyatul Asna yang berjumlah 173 siswa. Sedangkan jumlah sampel yang diambil adalah sebanyak $50 \% \times 173=87$ siswa. Sampel tersebut diambil dengan teknik Proportionate Stratified Random Sampling. Teknik pengambilan sampel ini proporsional dengan mempertimbangkan jumlah murid di setiap kelas, yaitu peneliti mengambil murid dalam jumlah prosentase yang sama dari tiap-tiap kelas dan dipilih secara acak. Untuk mempermudah pengumpulan data dan memperoleh hasil yang baik dan cermat, maka digunakanlah instrumen penelitian. Salah satu instrumen pengumpulan data dalam penelitian ini adalah dengan menggunakan kuesioner/angket. Kuesioner/angket ini peneliti digunakan untuk mengumpulkan data tentang variabel $\mathrm{Y}$ (perilaku keagamaan siswa) sedangkan variabel $X$ (prestasi belajar siswa) dengan dokumentasi. Kemudian instrument penelitian tersebut dikembangkan dengan kisi-kisi pada tabel 1.

Angket disusun dalam bentuk daftar cocok (checklist) dengan pilihan jawaban selalu, sering, kadang-kadang dan tidak pernah. Skor jawaban mempunyai nilai antara 1 sampai 4. Angket tersebut kemudian diuji cobakan pada 30 siswa untuk mengetahui kevalidan dan reliabilitasnya. Untuk menguji validitas instrument tersebut, terlebih dahulu dicari harga korelasi antara skor masing-masing item dengan skor total dengan rumus Pearson Product Moment yang selanjutnya dihitung dengan uji-t. Setelah diuji cobakan, maka diperoleh bahwa dari 18 item pertanyaan dalam kuesioner perilaku keagamaan, 6 item dinyatakan tidak valid dan 12 item yang yang lain dinyatakan valid. Setelah dilakukan uji validitas, maka langkah selanjutnya adalah menghitung koefisien reliabilitas instrumen. Reliabilitas adalah sejauh mana hasil suatu pengukuran dapat dipercaya, maksudnya apabila dalam beberapa pelaksanaan pengukuran terhadap kelompok yang sama diperoleh hasil yang relatif sama. Dalam penelitian ini, uji reliabilitas dilakukan dengan menggunakan teknik Formula Alpha Cronbach. Menurut Usman dan Akbar, koefisien reliabilitas $(\alpha)$ di atas 0,80 sudah memperlihatkan bahwa instrumen itu reliabel. Hasil dari pengujian reliabilitas instrumen menunjukkan bahwa nilai koefisien reliabilitas 
alpha sebesar 0,6521. Berhubung dalam instrumen tersebut masih ada beberapa item yang tidak valid, maka peneliti menghitung kembali reliabilitas instrumen dengan menghilangkan item-item yang tidak valid, sehingga diperoleh koefisien alpha sebesar 0,8858 . Hal ini menunjukkan bahwa instrumen tersebut memiliki reliabilitas yang tinggi sehingga memungkinkan atau layak digunakan dalam pengumpulan dan pengolahan data. Analisis data yang digunakan dalam penelitian ini yaitu analisis korelasi Tata Jenjang Spearman.

\section{Hasil Penelitian Dan Pembahasan}

\section{a. Prestasi belajar siswa.}

Saifuddin Azwar menyatakan bahwa prestasi belajar dapat dioperasionalkan dalam bentuk nilai raport, indeks prestasi studi, angka kelulusan dan predikat keberhasilan. Berdasarkan pernyataan tersebut, maka peneliti menggunakan nilai rata-rata raport siswa semester I. Dari data yang diperoleh, dapat diketahui bahwa nilai rata-rata prestasi belajar siswa mencapai 82,7. Adapun prosentase nilai tersebut secara lebih rinci dapat dilihat pada tabel 2.

Tabel 2 Rekapitulasi Data Prestasi

\begin{tabular}{ccc}
\hline Interval & Kategori & Prosentase \\
\hline$\leq 69$ & Kurang & - \\
$70-79$ & Sedang & $16 \%$ \\
$80-89$ & Baik & $84 \%$ \\
$90-100$ & Baik sekali & - \\
\hline
\end{tabular}

Tabel tersebut menunjukkan bahwa anak yang mendapatkan kategori baik dengan nilai 80-89 mencapai $84 \%$, sedangkan yang mendapatkan kategori sedang dengan nilai 70-79 mencapai 16\%. Maka dapat disimpulkan prestasi belajar siswa tergolong baik.

\section{b. Perilaku keagamaan siswa}

Berdasarkan kuesioner yang peneliti berikan, perilaku keagamaan siswa dapat diketahui dari tabel 3. 
Tabel 3 Rekapitulasi Data Perilaku Keagamaan

\begin{tabular}{ccc}
\hline Interval & Kategori & Prosentase \\
\hline$\leq 28$ & Kurang & $2,3 \%$ \\
$29-34$ & Sedang & $39,1 \%$ \\
$35-41$ & Baik & $56,3 \%$ \\
$42-48$ & Baik sekali & $2,3 \%$ \\
\hline
\end{tabular}

Tabel tersebut menunjukkan bahwa anak yang mendapatkan kategori baik mencapai 56,3\%, kategori sedang $39,1 \%$, kategori baik sekali 2,3\% dan kategori kurang 2,3\%. Maka dapat disimpulkan bahwa perilaku keagamaan siswa tersebut tergolong baik.

\section{c. Uji hipotesis}

Data-data yang telah dikumpulkan selanjutnya akan diuji hipotesis untuk membuktikan diterima atau ditolaknya hipotesis yang diajukan dalam penelitian ini. Adapun hipotesis yang diajukan dalam penelitian ini adalah "Adanya hubungan antara prestasi belajar dengan perilaku keagamaan siswa”. Untuk membuktikan hipotesis tersebut digunakan rumus korelasi Tata Jenjang Spearman dengan menggunakan IBM SPSS Statistics versi 22. Dari pengolahan data SPSS diperoleh hasil sebagai berikut:

Tabel 4 Signifikansi Koefisien Korelasi

\begin{tabular}{|c|c|c|c|c|}
\hline & & & $\begin{array}{l}\text { Prestasi } \\
\text { belajar }\end{array}$ & $\begin{array}{c}\text { Perilaku } \\
\text { keagamaan }\end{array}$ \\
\hline Spearman's & Prestasi & Correlation Coefficient & 1,000 & ,404*i= \\
\hline & belajar & Sig. (2-tailed) & &, 000 \\
\hline & & $\overline{\mathrm{N}}$ & 87 & 87 \\
\hline & Perilaku & Correlation Coefficient & $404^{\text {*ki }}$ & 1,000 \\
\hline & keagamaan & Sig. (2-tailed) & ,000 & \\
\hline & & $\overline{\mathrm{N}}$ & 87 & 87 \\
\hline
\end{tabular}

**. Correlation is significant at the 0.01 level (2-tailed).

Berdasarkan output di atas, maka diketahui bahwa nilai Sig. (2-tailed) $=0,000$ sedangkan koefisien korelasi antara variable $x$ (prestasi belajar) dan variable $y$ (perilaku keagamaan) adalah 0,404. Dari perhitungan ini dapat disimpulkan bahwa terdapat hubungan yang signifikan antara 
Prestasi Belajar dengan Perilaku Keagamaan Siswa dengan tingkat kekuatan hubungan tergolong sedang. Sehingga hipotesis alternatif (ha) diterima dan hipotesis nihil (ho) ditolak. Kemudian koefisien terdsebut dikuadratkan untuk mengetahui prosentase pengaruh prestasi belajar terhadap perilaku keagamaan siswa, sehingga diperoleh $0,404^{2}=0,163$. Hal ini berarti perilaku keagamaan siswa $16 \%$ ditentukan oleh prestasi belajar sedangkan lainnya (84\%) ditentukan oleh faktor lain.

Hasil penelitian ini juga sejalan dengan beberapa penelitian sebelumnya, diantaranya: Pertama, penelitian yang dilakukan oleh Siti Istifhamah yang berjudul "Studi Korelasi Prestasi Belajar Pai Terhadap Perilaku Keagamaan Pada Siswa SD Negeri Madyocondro Kec. Secang Kab. Magelang Tahun Pelajaran 2012/2013". Penelitiannya menghasilkan kesimpulan bahwa adanya korelasi yang sangat signifikan antara prestasi belajar PAl dengan perilaku keagamaan siswa. Ini dapat dibuktikan dengan hasil penelitian yang meyatakan $r x y$ $=0,830$ dan $r 1 \%$ nya adalah 0,345 sehingga semakin tinggi prestasi belajar PAl siswa semakin baik perilaku keagamaan siswa.

Kedua penelitian yang dilakukan oleh Dahlia dengan judul "Hubungan Antara Prestasi Belajar Akidah Akhlak Dengan Perilaku Keagamaan Siswa". Dari hasil pengolahan data diperoleh tabel nilai " $r$ " product moment pada taraf signifikansi $5 \%$ sebesar 0,361 , sedangkan pada taraf signifikansi $1 \%$ diperoleh 0,463 . Karena $r_{t}$ pada taraf signifikansi $5 \%$ lebih kecil dari $r_{0}(0,361 \leq 0,775)$ maka pada taraf signifikansi 5\% hipotesa nihil (ho) ditolak, sedangkan hipotesis alternatif (ha) diterima. Ini berarti bahwa pada taraf signifikansi $5 \%$ itu terdapat korelasi yang signifikansi antara variabel $X$ dengan variabel $Y$.

Ketiga, penelitian yang dilakukan oleh Nurlaela dengan Judul "Hubungan Prestasi Belajar Aqidah Akhlak Terhadap Akhlak Siswa Di MTs. Al-lkhlas Leuwinanggung Cimanggis Depok". Penelitiannya menghasilkan kesimpulan bahwa terdapat hubungan yang signifikan antara prestasi belajar Aqidah Akhlak dengan akhlak siswa hai ini ditunjukkan dengan hasil penghitungan korelasi product moment, dimana 
$r_{\text {hitung }}$ diperoleh sebesar 0,730 yang lebih besar dari $r_{\text {tabel }} 0,463$ pada taraf signifikansi 0,01 dan $N=30$. Jadi dapat dikatakan bahwa tinggi rendahnya prestasi belajar aqidah akhlak siswa akan diikuti oleh rendahnya akhlak siswa.

Keempat penelitian yang dilakukan oleh Siska Ristiana M. dengan judul "Hubungan Pengetahuan, Sikap, Tindakan Sarapan Dengan Status Gizi Dan Indeks Prestasi Anak Sekolah Dasar Di SD Negeri No.101835 Bingkawan Kecamatan Sibolangit Tahun 2009'. Penelitiannya menghasilkan kesimpulan bahwa terdapat hubungan yang bermakna antara tingkat pengetahuan sarapan dengan tindakan sarapan, tindakan sarapan dan status gizi menurut indeks TB/ $U$ dengan indeks prestasi, dan antara tindakan sarapan dengan status gizi menurut indeks $T B / U$ dan $B B / U$ dengan indeks prestasi.

Kelima dalam jurnal yang telah ditulis oleh Nooriza Janati dan Tarsis Tarmudji dengan judul "Pengaruh Kepercayaan Diri, Budaya Lokal Dan Pendidikan Agama Terhadap Hasil Belajar Mata Pelajaran Ekonomi Siswa Kelas XI IPS SMA Negeri 1 Demak Tahun Ajaran 2013/2014". Metode analisis yang digunakan adalah teknik analisis deskriptif. Metode analisis yang digunakan adalah regresi berganda. Analisis deskriptif kepercayaan diri siswa baik, budaya lokal sangat baik, pendidikan agama baik. Hasil penelitian ini secara statistik menunjukkan ada pengaruh kepercayaan diri, budaya lokal, pendidikan agama terhadap hasil belajar ekonomi siswa (37,7\%). Ada pengaruh kepercayaan diri terhadap hasil belajar mata pelajaran ekonomi siswa (16,56\%). Ada pengaruh budaya lokal terhadap hasil belajar mata pelajaran ekonomi siswa (10,50\%). Tidak ada pengaruh pendidikan agama terhadap hasil belajar mata pelajaran ekonomi siswa.

Berdasarkan paparan tentang korelasi antara prestasi belajar dengan perilaku keagmaan siswa dapat disimpulkan bahwa terdapat hubungan yang signifikan antara pretasi belajar dengan perilaku keagamaan siswa MTs Taufiqiyatul Asna Bukaan Keling Kepung Kab. Kediri. Hal tersebut diketahui dari besarnya koefisien korelasi antara prestasi belajar dengan perilaku keagamaan siswa adalah sebesar 0,404 dengan Sig.(2-tailed)=0,000. Dari besarnya koefisien 
korelasi dapat diketahui bahwa tingkat hubungan yang dimiliki adalah sedang. Oleh karena itu maka kontribusi prestasi belajar terhadap perilaku keagamaan siswa adalah $16 \%$.

\section{Penutup}

\section{Kesimpulan}

Berdasarkan hasil penelitian dan pembahasan di atas maka dapat disimpulkan:

1. bahwa Prestasi belajar siswa MTs Taufiqiyatul Asna tergolong baik, hal ini berdasarkan dari hasil rekapitulasi nilai raport siswa yaitu mencapai nilai rata-rata 82,7.

2. Berdasarkan rekapitulasi data perilaku keagamaan siswa yang diperoleh dari kuesioner menunjukkan bahwa perilaku keagamaan siswa di MTs Taufiqiyatul Asna tergolong baik yaitu dengan prosentase 56,3\% baik, 39,1\% sedang, 2,3\% baik sekali dan 2,3\% kurang.

3. Terdapat hubungan yang signifikan antara prestasi belajar dengan perilaku keagamaan siswa dengan tingkat kekuatan hubungan antara keduanya tergolong sedang. Hal ini berdasarkan dari hasil penghitungan data dengan rumus Tata Jenjang Spearman menggunakan program IBM SPSS Statistics Versi 22 yang menunjukkan nilai koefisien korelasi antara variabel $x$ dan variabel $y$ sebesar 0,404 dengan nilai Sig. (2-tailed) $=0,000$. Kemudian koefisien tersebut dikuadratkan untuk mengetahui prosentase pengaruh prestasi belajar terhadap perilaku keagamaan siswa, sehingga diperoleh $0,404^{2}=0,163$. Hal ini berarti perilaku keagamaan siswa 16\% ditentukan oleh prestasi belajar sedangkan lainnya (84\%) ditentukan oleh faktor lain.

\section{Saran}

Berdasarkan hasil penelitian di atas, peneliti mengajukan saran-saran sebagai berikut:

Pertama, sekolah hendaknya mengadakan buku kegiatan siswa yang harus diisi oleh siswa dan diketahui oleh orang tua/wali. Buku kegiatan tersebut berisikan kegiatan keagamaan apa saja yang dilaksanakan dalam satu hari tersebut. 
Kedua, agar memperoleh hasil yang lebih baik lagi, hendaknya guru lebih meningkatkan mutu pembelajaran misalnya dengan menggunakan berbagai variasi metode dalam pengajarannya. Dalam setiap pembelajaran guru juga hendaknya memberikan bimbingan, penyuluhan serta contoh perilaku beragama yang baik kepada siswanya sehingga para siswa menjadi termotivasi untuk berperilaku baik.

Ketiga, dalam upaya meningkatkan perilaku keagamaan kepada anak didik, seharusnya dari pihak orang tua di rumah ataupun guru di sekolah dapat memberikan contoh terlebih dahulu dengan menunjukkan perilaku yang tidak menyimpang dari norma-norma agama ataupun norma sosial. 


\section{Daftar Pustaka}

Agustin, Risa. (2006) Kamus Ilmiah Populer. Surabaya: Serba Jaya,

Ahmadi, Abu dan Widodo Supriyono (2013.). Psikologi Belajar. Jakarta: Rineka Cipta.

Anak Pertama. (2015). "Psikologi Agama: Orientasi Sikap dan Perilaku Keagamaan" (online), (http://wahyutyas86.blogspot.com/2011/07/psikologiagama-orientasi-sikap-dan.html, 21 Juli 2011, diakses tanggal 27 Januari 2015).

Arikunto, Suharsimi. (2002). Prosedur Penelitian Suatu Pendekatan Praktek. Jakarta : Rineka Cipta.

-..-.-.. (2006). Prosedur Penelitian Suatu Pendekatan Praktek. Jakarta: Rineka Cipta.

Azwar, Saifuddin, (2000). Reliabilitas dan Validitas. Yogyakarta : Pustaka Pelajar Offset,

Bukhari, Imam. Shahih al Bukhari, juz 5. Beirut: Darul kitab alilmiah, t.th.

Dahlia. (2009). "Hubungan Antara Prestasi Belajar Akidah Akhlak Dengan Perilaku Keagamaan Siswa”. Skripsi tidak diterbitkan. Jakarta: UIN Syarif Hidayatullah Jakarta.

Depag RI. (2006). Alqur'an dan Terjemahannya. Surabaya: Karya Agung.

Depdiknas. (2001). Kamus Besar Bahasa Indonesia. Jakarta: Balai Pustaka.

Hudri, Said. (2015). "Pengertian Belajar Dan Prestasi Belajar Menurut Para Ahli”, (online) (http://expresisastra.blogspot.com/2014/01/PengertianBelajar-dan-Prestasi-belajar-menurut-para-Ahli.html, diakses tanggal 27 Januari 2015).

Istifhamah, Siti. (2012). "Studi Korelasi Prestasi Belajar PAI Terhadap Perilaku Keagamaan Pada Siswa SD Negeri Madyocondro Kec. Secang Kab. Magelang Tahun 
Pelajaran 2012/2013”. Skripsi tidak diterbitkan. Salatiga: STAIN Salatiga.

Jalaluddin. (2012). Psikologi Agama, Memahami Perilaku dengan Mengaplikasikan Prinsip-Prinsip Psikologi. Jakarta: Rajawali Pers.

Janati, Nooriza dan Tarsis Tarmudji. (2014). "Pengaruh Kepercayaan Diri, Budaya Lokal Dan Pendidikan Agama Terhadap Hasil Belajar Mata Pelajaran Ekonomi Siswa Kelas XI IPS SMA Negeri 1 Demak Tahun Ajaran 2013/2014", Economic Education Analysis Journal, No. 3, 2014.

Mahmud. (2010). Psikologi Pendidikan. Bandung: CV Pustaka Setia,

Margono. (2004). Metodologi Penelitian Pendidikan. Jakarta: Rineka Cipta,

Nurlaela. (2010). “Hubungan Prstasi Belajar Aqidah Akhlak Terhadap Akhlak Siswa Di MTs Al-lkhlas Leuwinanggung Cimanggis Depok". Skripsi tidak diterbitkan. Jakarta: UIN Syarif Hidayatullah Jakarta,

Rakhmat, Jalaluddin. (2003). Psikologi Agama. Bandung: PT Mizan Pustaka.

Ristiana M, Siska. (2009). "Hubungan Pengetahuan, Sikap, Tindakan Sarapan Dengan Status Gizi Dan Indeks Prestasi Anak Ssekolah Dasar Di Sd Negeri No.101835 Bingkawan Kecamatan Sibolangit Tahun 2009".Skripsi tidak diterbitkan. Medan: USU Medan.

Sugiyono. (2014). Metode Penelitian Pendidikan. Bandung: Alfabeta.

Syukur, Suparman. (2004). Etika Religius. Yogyakarta: Pustaka Pelajar.

Uno, Hamzah B. (2008). Orientasi Baru dalam Psikologi Pembelajaran. Jakarta: Bumi Aksara. 
132 Prestasi Belajar dan Perilaku

Wikipedia. (2015). "Prestasi", (online)

(http://id.m.wikipedia.org/wiki/prestasi, diakses tanggal 18 Maret 2015).

Yusuf Nur, Edy. (2013). Mutiara Akhlak Islami. Yogyakarta: SUKA-Press, 2013. 